\title{
MULTIMODAL ANALYSIS OF WARDAH LIPSTICK ADVERTISEMENT
}

\author{
Aning Rustanti Raharjo ${ }^{1}$, Didin Nuruddin Hidayat ${ }^{2}$, Alek ${ }^{3}$, Nasifuddin Jalil ${ }^{4}$ \\ ${ }^{1234}$ UIN Syarif Hidayatullah Jakarta, Indonesia \\ Ianingrustantiraharjo@gmail.com, 2didin.nuruddin@uinjkt.ac.id, 3alek@uinjkt.ac.id \\ ${ }^{4}$ nasifuddin@uinjkt.ac.id
}

\begin{abstract}
Advertising is utilized to promote certain products and attract the attention of potential customers to purchase the products. In this study, the researchers use advertisements broadcasted through an electronic form, namely Wardah lipstick advertisement. The advertisement is audiovisual, and the form of the message included sound and moving images. The analysis in this study used a semiotic approach and multimodal analysis focusing on multimodal systems, including aspects of linguistics, visual, audio, gestural, and location. This study used qualitative research methodology by applying a descriptive analysis in the research. The study found that this advertisement covers the five aspects of the multimodal semiotic system: linguistics, visuals, audio, gestural, and location. These five aspects are integrated to convey the core message in Wardah lipstick advertisement. Finally, this research found the meaning contained in an advertising message. The advertisement structure was also composed of verbal and visual text to persuade and affect buyers' decisions.
\end{abstract}

Keywords: Advertisement, Discourse Analysis, Linguistic, Multimodal

\begin{abstract}
ABSTRAK
Iklan digunakan untuk mempromosikan produk tertentu dan menarik perhatian orang atau calon konsumen untuk membeli produk tersebut. Dalam penelitian ini, peneliti menggunakan iklan yang disiarkan melalui bentuk elektronik yaitu iklan lipstik Wardah. Iklan ini bersifat audio visual, dan bentuk pesannya termasuk suara dan gambar bergerak. Analisis dalam penelitian ini menggunakan pendekatan semiotik dan analisis multimodal yang berfokus pada sistem multimodal, yang meliputi aspek linguistik, visual, audio, gestur, dan lokasi. Penelitian ini menggunakan metodologi penelitian kualitatif dengan menerapkan analisis deskriptif dalam penelitiannya. Hasil penelitian menemukan bahwa iklan ini mencakup lima aspek dari sistem semiotik multimodal, yaitu aspek linguistik, visual, audio, gestur, dan lokasi. Kelima aspek tersebut terintegrasi untuk menyampaikan pesan inti dalam iklan lipstik Wardah. Akhirnya, penelitian ini menemukan makna yang terkandung dalam pesan iklan. Selain itu, struktur iklan terdiri dari teks verbal dan visual untuk membujuk dan mempengaruhi keputusan pembeli.
\end{abstract}

Kata Kunci: Iklan, Analisis Wacana, Linguistik, Multimodal

\section{INTRODUCTION}

Language is a tool to communicate with others. Humans communicate with each other, individuals to individuals, individuals with groups, or even groups with groups using language. Language is the tool that humans can use to communicate with others. According to (Pettinger, 2013), language is a communication system in which thoughts are transmitted (transmitted) through the voice (as in a conversation) 
or symbols (as in written words or physical cues).

(Turhan, 2017) concluded that since the advertising itself needs to convince the consumer to purchase and use the product, the language used in advertising must be simple to understand, catchy and convincing. In other words, when marketing a product, the language used in advertising is very significant. People will buy a product if the language used is interesting. Advertising language can influence and persuade consumers to buy products through language, image or picture, sound, or gesture. As explained by (Eynullaeva, 2018), advertisement contains a complex meaning. It is a mixture of text and images and is usually developed through graphic artists and copywriters' collaboration. However, in audiovisual commercials, the verbal and the visual can also be supplemented by music. To recognize the complexities of meaning, it is necessary to study multimodal in an advertisement; since multimodal analysis aims to understand the power and meaning of a text containing several modes such as verbal, visual, and aural (Kress \& Lueewen, cited in Bo, 2018). In this research, the researchers did a multimodal analysis of beauty product advertisements. The use of visual and verbal language in beauty product advertisements is the easiest way to manipulate the customers' beliefs. It will gain their desire to buy the product because of the advertisement's visual and verbal elements.

\section{LITERATURE REVIEW}

The various meaning modes, including visual, linguistic, audio, gestural and technical modes used for meaning building, are taken into account in a multimodal approach to text analysis (Shamini Periasamy et al., 2014). It notes that if the text is realized from a combination of two or more semiotic systems, a text is called multimodal. In a text, there are five multimodal semiotic systems, namely: 1) Linguistic: vocabulary, generic structure and oral and written language grammar, 2) Visual: colour, vector and point of view in still and moving images, 3) Audio: music and sound effects length, pitch and rhythm, 4) Gestural: facial expression and body language movement, speed, and stillness, and 5) Spatial: proximity, direction, the position of layout and organization of objects in space (Anstey \& Bull in Fitriawati et al. 2019).

\section{Visual Grammar}

The systematic and detailed method for multimodal discourse analysis in Reading Images is Visual Grammar. Visual Grammar considered that language is a social semiotic type. In discourse, the fusion of language and other semiotic forms makes the speech meaningful and vivid to the readers. As explained by (Ping, 2018) visual Grammar has three basic meanings: representative meaning, interactive meaning, and compositional meaning. Representative meaning refers to the faithful reproduction of people's objective world, human actions, places, and even people's inner world. It consists of two processes: the conceptual process and the narrative 
process. The narrative process completes the process of action, the reaction process, the verbal and mental process, while the emotional process and the existential process are included in the logical process. Interactive definition, to make it plain, is the explanation of the image marker relationship, image representation and readers. The components are touch, attitude, distance and modality, even in the interactive sense. Modality is divided into three forms of Visual Grammar: high modality, middle modality and low modality that can be shown by color, illumination, etc. Compositional importance implies the whole multimodal discourse layout. Data significance, framing and salience are the elements composed of the compositional sense. The value of information is the location of specific information, such as new and old information. Framing means whether or not there are such devices for linking the elements of the debate. Salience refers to various levels of components, such as context and foreground, for readers.

\section{Advertisement}

An advertisement is a form of promotion for individuals, organizations, or companies to convey their vision and mission. (Koçyiğit, 2018) pointed out that marketing provides the benefits of oral contact and engagement between individuals and brands on network channels. In this way, consumer brands can build more strategies and tactics through input from both customers so that they can find solutions to their issues in a short time for both brands. Television has kept the title of the largest mass medium used for advertisement for more than 60 years. Due to its pervasiveness, effect and targeting capabilities, television is an essential component of a media strategy. Television and advertising present a lethal combination and have become an integral part of modern society. Television Advertisements typically play a part in either launching a product that enhances the product's familiarity or encouraging the product to buy. (Lim-fei et al., 2017) noted that advertising is one of the most visible advertising techniques and has gained a great deal of publicity in the last ten to fifteen years. Advertising can not only alter thoughts but have a subliminal message. Television Advertisements typically play a part in either launching a product that enhances the product's familiarity or encouraging the product to buy. Advertising is one of the most visible advertising techniques and has gained a great deal of publicity in the last ten to fifteen years. Today's advertisement appears to exert a far-reaching impact on people's everyday lives anywhere and ever-present. To encourage buying choices, commercials create self-concepts. Television advertising uses attention-grabbing tricks such as catchy and pleasing songs, lyrics, jingles, humour and repetitive messages. The effect of advertising is greater on television than on print or radio media. Advertising can not only alter thoughts but have a subliminal message.

Several attempts have been made to study multimodal analysis is an

advertisement. Some researchers have mentioned the importance of multimodal analysis in an advertisement (Hidayat et al., 2017; Hu \& Luo, 2016; Nashihah, 2016). For instance, multimodal analysis of Tmall's Double Eleven advertising was done by 
(Hu \& Luo, 2016). The findings showed that visuals components serve as a massive attraction to the audience and adequately explain consumption by appealing to the social and cultural state. It also sheds some light on raising customers' awareness by presenting how commercial producers practice psychological manipulation on the audience. They also claim that the visual and language aspect in advertisements can attract and persuade consumer buying. Another study was done by (Nashihah, 2016) entitled Discourse analysis of Rexona Advertisements. The result showed that advertisers used linguistics devices to attract women, such as a direct address, optimistic vocabulary, headlines, and catchy slogans. Besides, in this analysis, the language used in beauty product advertising is politically disputed. From the explanation mentioned above, the two advertisements cover the visual, language, and linguistics aspects. On the other hand, Wardah lipstick advertisement has all the components displaying verbal images and expressions that show the power of announcements and enhancers.

Besides, the visual structure in this advertisement with its lead components displays proportional size. Position and color in an interpersonal way and the actor's make-up is essential. The setting makes use of the circumference location in property primary and secondary colors produce complementary contrast. The two research studies before using different theories of research methods, research subjects are also expanding, such as three-dimensional space (Stenglin, 2008), picture, and comic books (Feng \& O'Halloran, 2012; Birner, 2015). On the other hand, this research used theory developed from a combination of multimodal theory (Anstey, M., \& Bull, 2010) and multimodal analysis by Kress and Van Leeuwen, cited in Bo (2018). The researchers are interested in research to overcome the gaps by analyzing the verbal and visual meaning in Wardah lipstick advertisement. This research aims to analyze the multimodal semiotic systems text in Wardah lipstick advertisement and describes the verbal and visual meaning in the advertisement. Finally, this research can find out the meaning contained in an advertising message, the advertisement structure consists of verbal, visual text in persuading the people and many things can be examined from language advertising in terms of language that can affect buyers so that Wardah is the best-selling cosmetics in Indonesia

Based on the previous study, it seems to indicate that advertisements can be analyzed through critical discourse analysis use of multimodal analysis. This research attracts two questions: what is the semiotic multimodal in the Wardah Lipstick advertisement?, and what is the verbal and visual meaning in the Wardah Lipstick advertisement?

\section{RESEARCH METHODS}

This research was conducted in a qualitative research methodology that utilized the descriptive approach to conduct the research. Qualitative research systematically describes and interprets problems or phenomena for the individual or 
population being studied, as explained by (Mohajan, 2018) and to generate fresh concepts and theories. Besides, this type of research focuses on words rather than numbers and observes the world in its natural environment, interpreting situations to understand the meanings people make from day to day life (Walia, 2016). The data were in the form of an image collected from the screenshot of the advertisement video. The researchers captured each advertisement video scene consisting of an image, written text, and logo brands in getting the data. Then, the researcher transcribed and identified the text and visual information found in the advertisement video.

The researchers analyzed the data descriptively, and the result was in the form of an explanation. This research described the multimodal analysis using a semiotic approach in Lipstick matte Wardah advertisement. This study's data were texts, images, sounds, and gestures found in Wardah cosmetic advertisement video. The multimodal analysis model was developed from a combination of multimodal theory (Anstey, M., \& Bull, 2010) and multimodal analysis by Kress \& Van Leeuwen, cited in (Bo, 2018). To analyze the data, the researchers carried out some stages, for instance, analyzing the linguistic, visual, audio, gesture, and spatial in the advertisement, interpreting the codes, writing the findings, and concluding the results. Machin \& Mayr (2012) explained qualitative data analysis techniques: (1) Data documentation and data collection method, (2) Data organization/categorization into concepts, (3) Data link to show how one definition may influence another, (4) Corroboration/legitimization by testing alternative interpretations, (5) Disconfirming facts and looking for negative cases-representing the account (reporting the findings).In this research, the first step of this analysis must treat an image like language. This means that the image is believed to be verbal language functions; how the image represents experience. This can be seen in the image in how, for example, objects or represented participants or items in the image 'related' to the other object. Second, after seeing the image with a three-metaphysical perspective language, the image analysis procedure's next step is the description or identification. Furthermore, (Machin \& Mayr, 2012) describe what is in the image facilitates good analysis. The researchers illustrate in detail every major element in an image, including how this element is displayed. After depiction or identification, the researcher is doing critical analysis or significance. In this context, mastery and understanding of meaning, connotation and denotation of internal elements, the context of the image being analyzed is very helpful.

\title{
FINDINGS AND DISCUSSION
}

\section{Findings}

After analyzing the advertisement, it was revealed that:

\author{
1. Linguistic Analysis
}


The Wardah Exclusive Matte Lip cream ad is played by Tjahyana Saphira and Sheila Firdaus using a combination of spoken and written languages. The oral speech was spoken by Tjahyana Saphira, who is a female idol today. Tjahyana represents the beauty of Indonesian girls today.

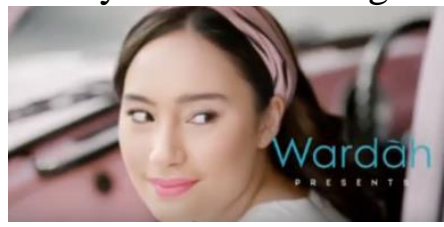

(30 seconds).

*Backsound 2 seconds

$\mathrm{S}: \mathrm{Hai}(\mathrm{Hi})$

T: Baruya?( Is it a new one?)

T: Cobadeh Lip Cream Wardah dengan warna warni yang tahan lama.

Percaya diri melangkah coba hal baru jadikan dunia kita lebih berwarna, nyaman lakukan yang kita mau. (you must try Wardah Lip cream with long-lasting colorful. It makes you confident in trying new things. Make our world more colorful and you can do what you want.)

T: Dengan matte Lip Cream Wardah exclusive formula baru lembut warnai senyummu.(Matte Lip Cream Wardah exclusive new formula gently color your smile.)

*2 second

Feel the color, Berani coba (dare to try?)

The verbal variety used in the new formula exclusive to Wardah matte Lip cream is formal and informal. Next, stress the importance of being found in the verbal variety of verbal advertising. This is enhanced and emphasized by the inclusion of written variety manifested byproduct and trademark emblems in the form of visual emblems.

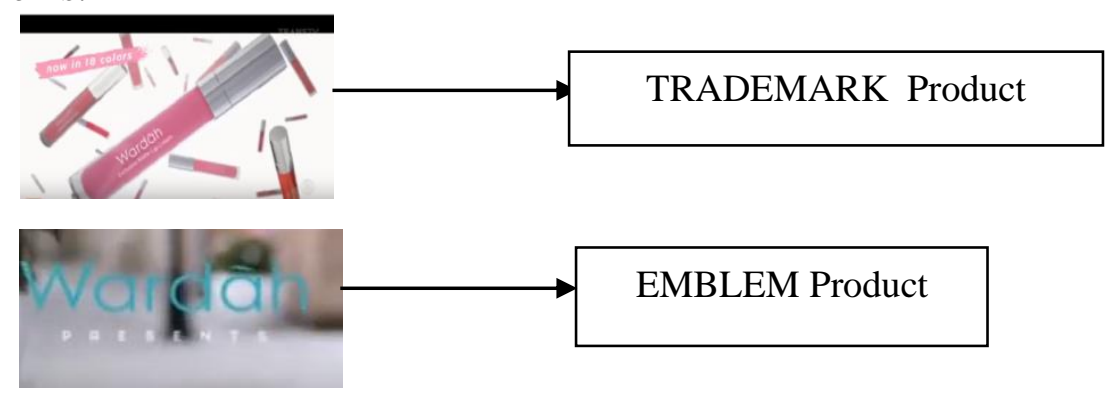

2. Visual Analysis

Three images represent Wardah's lipstick advertisements' visual appearance, namely the visuals of the advertising models, product visuals, and visual emblems (product logos). 


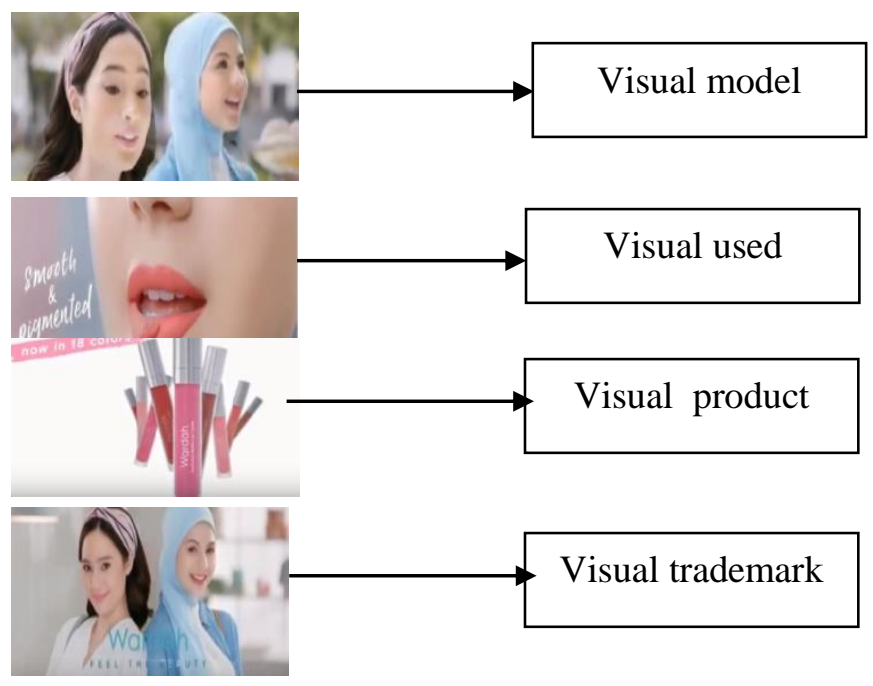

The combination of advertising star visuals and product visuals generates interpersonal meaning between and the viewer in commercials. interaction is realized by eye contact between participants and the audience that acts as a query. This situation demonstrates that the participant clarifies the products offered. The next process is the meaning of the products provided verbally by participants. Verbal text that illustrate the benefits of offered goods.

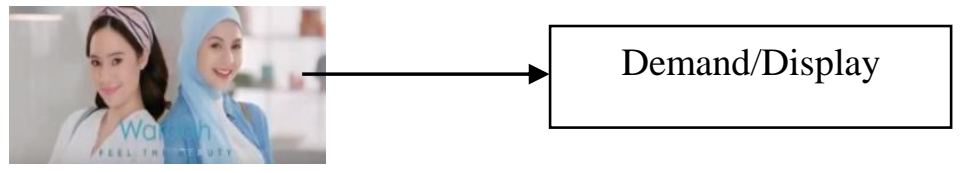

Demand is a direct interaction that manifests through eye contact between the participants and the viewer that looks at the viewer.

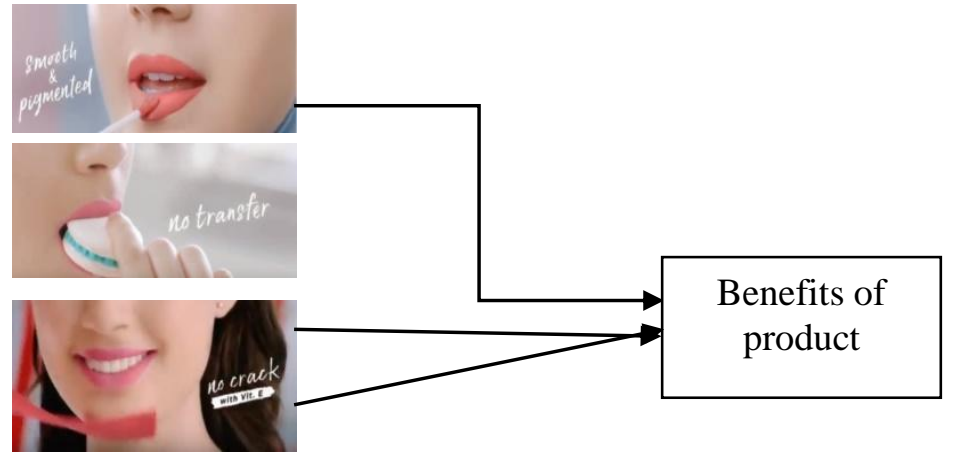

The three images are included in the set, which has a background function that explains the advantages of the products offered. The Additive is a relationship that explains various visual information through verbal text, which is complementary to the product's advantages. 


\section{Audio Analysis}

The music in this commercial that accompanies the action is only in the form of music. The type of rhythmic music used in this commercial is to demonstrate or give the impression that Wardah Lipstick items can generate a powerful and quick spirit of action. This is being better, or the use of verbal is an affirmation of the product's supremacy so that the spirit, Wardah lipstick, and the use of silence is the transmission to the viewer of product excellence. This is getting stronger or is an affirmation of the superiority of the product is the use of verbal so that the spirit, Wardah lipstick, and silence are the delivery of product excellence to the audience on the visual activity of participants.

\section{Location /Spatial}

Overall, the distance analysis between one image and the other image already reveals this advertisement's integrated significance. The image has its meaning, but each image's meaning supports the meanings of each other's images. The depiction of the spirit of operation participants, product excellence, and product ease is shown by the distance from the active participants' images and the process of processing Wardah Lipstick and the lead at the end of the advertisement image. This lead serves to give an impression and a deep meaning to the user. The lead in this ad is a Locus of Attention (LoA) realized in the following image:

\section{5) Gesture Analysis}

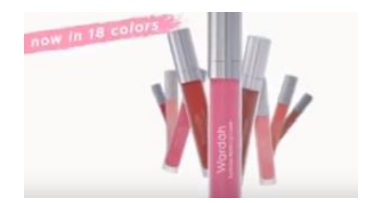

Body movement and speed, and facial expressions are the gesture of the participants. The gesture in this advertisement is realized from the participants' activities responding to his daily life, which is full of enthusiasm. This is reflected in the process and objectives of the actress and active and passive participants, where participants have a process about the direct impact that can be obtained from consuming the products they offered. Verbal participants in this advertisement show active and passive participants.

Verbal

Soften your smile
Image

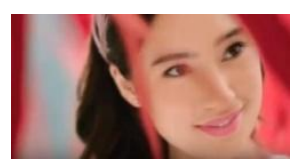

\section{Discussion}

The findings above show that Wardah Lipstick advertisement consists of five parts (linguistic, visual, audio, spatial, and gesture) based on multimodal analysis. It is supported by the previous statement by Anstey and Bull, cited in Amatullah et al. 
(2019). Thus, language studies are inseparable from the social context (Gana et al., in Suprakisno, 2015). One context is known in TLSF theory in the context of the situation (register). In the context of the situation, two terms are always used by TLSF experts in different ways, namely: situational and discoursal. The term 'situational' has the noun 'situation' used here to present the semiotic space of the TLSF concept 'situation context' or register as variety in a language or register. The advertisement uses language, image or picture, sound, or gesture. The Advertisement contains complex meaning in conveying a message presented not only through linguistic or verbal elements but also through visual elements. To understand the complexities of meaning, it is necessary to study multimodal in an advertisement; since multimodal analysis aims to understand the power and meaning of a text containing several modes such as verbal, visual, and aural (Kress \& Lueewen in Bo, 2018).

Significantly based on the research, multimodal learning can improve students' communicative competence, cultural understanding, and attitudes towards language (Farias, Miguel, \& katica, 2007). Through the form of language (encode) can represent a world that is socially constructed. The emphasis is on the social context of language, and namely, function social determines the form of language and how it is developed. Furthermore, literacy is multimodal directed at various sources of text that can produce meaning. Literacy multimodal is an effort to understand various ways of representing knowledge and making meaning. The focus of multimodal literacy is on the design of discourse by investigating the contributions of various semiotic sources (verbal, visual, and spatial), which is deployed through various modalities and interaction and integration in the process of text coherence. Multimodal literacy considers how linguistic choices and visuals fulfil the purpose of the text, audience, and context. Those choices work together in the organization and develop information and ideas (Lim-fei et al., 2017). Multimodal in learning is a process, way, and makes people learn by utilizing various text sources as a learning media. The intended media is not limited only through text but also utilizes the elements of motion and visual elements.

\section{CONCLUSION}

Based on the results of the multimodal analysis on Lipstick Wardah advertisement, the following conclusions can be drawn: (1) There is a multimodal semiotic system in Lipstick Wardah advertisement, (2) Each multimodal semiotic system is closely interrelated produce advertising meaning and semiotic, (3) The resulting message is quite comprehensive and easily understood by the audience. Wardah advertisement has visual and picture meaning. It is the easiest way to manipulate customers' beliefs. It will gain their desire to buy the product because of the advertisement's visual and verbal elements (Hidayat et al., 2020). The text is completed in speech alone, pictures, motion, graphics, and influencing acts of communication, specifically in learning. Collaboration between literacy and multimodal makes students understand the position, gaze, position, posture, gesture, 
and action with books and boards and talk in the classroom. Besides, multimodal research can be used to examine student's performance in the class, student's identity, examination, and official curriculum. The existence of multimodal educators/teachers allows us to approve different student needs in a language learning environment. The study is expected to contribute to the academic field, especially on the discourse analysis of multimodal analysis in advertisement language. The study is also expected to give additional information for further research studies on the same topic. Further research studies are suggested to analyze both printed and electronic advertisements to apply the semiotics and multimodal analysis comprehensively.

\section{BIBLIOGRAPHY}

Amatullah, F., Rosa, R. N., \& Padang, U. N. (2019). An Analysis of Multimodal In Beauty Product. 8(1).

Anstey, M., \& Bull, G. (2010). Helping teachers to explore multimodal texts". Curriculum and Leadership. vol 8 (16), 11.

Birner, A. (2015). Review of Painter, C., J. R. Martin \& L. Unsworth (2013) Reading Visual Narratives: Image Analysis of Children's Picture Books . Australian Review of Applied Linguistics, 38(1), 85-88. https://doi.org/10.1075/aral.38.1.05bir

Bo, X. (2018). Multimodal Discourse Analysis of the Movie Argo. English Language Teaching, 11(4), 132. https://doi.org/10.5539/elt.v11n4p132

Eynullaeva, E. (2018). Relational Designs in Literature and the Arts. Relational Designs in Literature and the Arts, January 2012. https://doi.org/10.1163/9789401208567

Farias, Miguel, Oblinovic katica, O. R. (2007). Implications of Multimodal Learning Models for foreign language teaching and learning 1. Colombian Applied Linguistics Journal, 9, 2-3.

Feng, D., \& O’Halloran, K. L. (2012). Representing emotive meaning in visual images: A social semiotic approach. Journal of Pragmatics, 44(14), 2067-2084. https://doi.org/10.1016/j.pragma.2012.10.003

Hidayat, D. N., Abrizal, A., \& Alek, A. (2017). A Multimodal Discourse Analysis of the Interpersonal Meaning of a Television Advertisement in Indonesia. Indonesian Journal of English Education, 5(2), 119-126.

Hidayat, D. N., Septiawan, Y., \& Sufyan, Y. (2020). Critical Discourse Analysis and Its Potential for English Language Teaching: A study on Beauty Advertisement Products in Indonesia. Asian ESP Journal, 16(2.2), 271-297.

Hu, C., \& Luo, M. (2016). A Multimodal Discourse Analysis of Tmall's Double 
Eleven Advertisement. English Language Teaching, 9(8), 156. https://doi.org/10.5539/elt.v9n8p156

Koçyiğit, M. (2018). A literature review on the viral advertising narrative structure. In Brand Culture and Identity: Concepts, Methodologies, Tools, and Applications (Vol. 3, pp. 1363-1379). IGI Global. https://doi.org/10.4018/978-15225-7116-2.ch073

Lim-fei, V., Tan, S., \& Yin, K. (2017). Multimodal Translational Research: Teaching Visual Texts. New Studies in Multimodality: Conceptual and Methodological Elaborations, December 2016. https://doi.org/10.5040/9781350026544.0014

Machin, D., \& Mayr, A. (2012). How to do Critical Discourse Analysis - A Multimodal Introduction. London SAGE, 4, 12.

Mohajan, H. K. (2018). Qualitative Research Methodology in Social Sciences and Related Subjects. Journal of Economic Development, Environment and People, 7(1), 23. https://doi.org/10.26458/jedep.v7i1.571

Nashihah. (2016). Discourse analysis of Rexona advertising (Thesis). State Islamic University Sunan Kalijaga. Yogyakarta.

Pettinger, R. (2013). Organizational Behaviour. In Organizational Behaviour. https://doi.org/10.4324/9780203857595

Ping, K. (2018). A Visual Grammar Analysis of Lesaffre's Website. Advances in Language and Literary Studies, 9(6), 38. https://doi.org/10.7575/aiac.alls.v.9n.6p.38

Shamini Periasamy, M., Gruba, P., \& Subramaniam, G. (n.d.). A Multimodal Literary Analysis of a Television Commercial. In The Southeast Asian Journal of English Language Studies (Vol. 3, Issue 3).

Stenglin, M. (2008). Binding: A resource for exploring interpersonal meaning in three-dimensional space. Social Semiotics, 18(4), 425-447. https://doi.org/10.1080/10350330802469904

Suprakisno. (2010). Analisis Multimodal Iklan “Indomie ” Suprakisno Fakultas Bahasa dan Seni Universitas Negeri Medan.

Turhan, B. (2017). Critical Discourse Analysis of Advertising: Implications for Language Teacher Education. International Journal of Languages' Education, I(Volume 5 Issue 4), 213-226. https://doi.org/10.18298/ijlet.2301

Walia, R. (2016). A Saga of Qualitative Research. Sociology and Criminology-Open Access, 04(01), 1-4. https://doi.org/10.4172/2375-4435.1000124 